\title{
Supporters and Opponents of Prohibition
}

\author{
Iowa in 1917 \\ Thomas G. RYAN
}

For the LAST 130 years Iowans have struggled with the problem of establishing a satisfactory method of regulating the sale, the possession, and the consumption of alcoholic beverages. From the 1855 passage of a prohibitory law to late 1970s and early 1980s suggestions for modification of state-owned liquor stores, Iowa legislators and voters have periodically expressed their views regarding the best methods of controlling access to beer, wine, and ardent spirits. As a number of studies in the "new political history" and the "new social history" demonstrate, the citizens of other states also have manifested high levels of concern regarding this subject. ${ }^{1}$

Questions of public policy in regard to alcoholic beverages were particularly salient in the late nineteenth and early twentieth centuries, culminating in the passage of prohibition laws in

An earlier version of this article was presented to the 1981 meeting of the Missouri Valley History Conference. The author would like to thank Joseph F. Wall of Grinnell College and two anonymous Annals of lowa referees for their comments and suggestions on earlier drafts.

1. See among others, Jack S. Blocker, Retreat from Reform: The Prohibition Movement in the United States, 1890-1913 (Westport, Conn., 1976); 
thirty-six of the forty-eight states prior to the addition of the Eighteenth Amendment to the federal Constitution in 1919. Although most state dry laws were passed in the decade following 1906, the battle for, and against, prohibition shaped political life in many states for at least twenty-five years before that date.

During the last two decades of the nineteenth century, Iowa drys were among the most successful in the nation as they persuaded the 1880 and 1882 sessions of the General Assembly to approve a prohibition amendment to the state constitution. If ratified by the voters, it ". . . would join Iowa with Kansas and Maine as the driest states in America."2 Although 55.3 percent of the voters cast affirmative ballots in the 1882 referendum on the proposed prohibition amendment, the state Supreme Court ruled the amending process unconstitutional. Undaunted by this setback, the ". . . drys rammed through three of the stiffest prohibition laws in America at the 1884 session of the Iowa legislature. . ..." ${ }^{\prime 3}$

Success for the prohibitionists, however, soon generated a countermove as growing numbers of Iowans began to argue that the state had moved too far in a dry direction. Responding to the resurgence of wet sentiment, in 1894 the legislature softened the 1884 statutes by authorizing a form of local option, the Mulct Law. Under this legislation, some Iowa communities were dry; others were wet. ${ }^{4}$

In 1908, however, Iowa drys resumed their offensive. In the legislative sessions of 1909 through 1917 more dry legisla-

Richard Jensen, The Winning of the Midwest: Social and Political Conflict, 1888-1896 (Chicago, 1971), especially chapter four; and two works by Ballard Campbell, Representative Democracy: Public Policy and Midwestem Legislatures in the Late Nineteenth Century (Cambridge, Mass., 1980), especially chapter six; and "Did Democracy Work? Prohibition in Late Nineteenth Century Iowa: A Test Case," Journal of Interdisciplinary History 8 (Summer 1977), 87-116.

2. Jensen, Winning of the Midwest, 93.

3. Ibid., 98; Dan Elbert Clark, "Recent Liquor Legislation in lowa," lowa Joumal of History and Politics 15 (January 1917), 44-45.

4. Clark, "Recent Liquor Legislation," 46; Campbell, Representative Democracy, 147. 
tion was introduced than at any time since the 1880 s. In the first four years of the new dry era the number of Iowa establishments selling alcoholic beverages legally decreased by over 50 percent. Increasingly successful in passing the legislation they wanted, Iowa drys then turned to the final step, the addition of a prohibition amendment to the state constitution, the victory the Iowa Supreme Court had denied them thirty years earlier. In 1915 and in 1917 both houses of the General Assembly approved overwhelmingly the proposed amendment. On October 15, 1917, 428,383 Iowa men went to the polls to register their verdict on the prohibition amendment. Unlike their state legislators, they rejected the proposal - 213,747 (49.9 percent) voting for it, 214,636 (50.1 percent) casting negative ballots. ${ }^{5}$

Increased legislative activity by Iowa drys during the second decade of the twentieth century paralleled similar activity by prohibitionists throughout the nation. Between 1907 and 1919, thirty-one states enacted prohibition statutes and/or constitutional amendments, bringing the total number of legally dry states to thirty-six. Less successful in other-chiefly northeastern - states, dry forces also initiated a campaign for a federal prohibition amendment. Congress passed the proposed Eighteenth Amendment in December 1917, eleven months after the Iowa General Assembly's second approval of the proposed state prohibition amendment, two months after Iowa men narrowly rejected it. Despite their constituents' rejection of the state amendment, members of the General Assembly reaffirmed their support for constitutional prohibition when both houses voted overwhelmingly to ratify the federal dry amendment in the first

5. Clark, "Recent Liquor Legislation," 46-66. The House approved the amendment 91-14, with 3 abstentions, in 1915; 100-5, with 3 abstentions, in 1917. The Senate passed the amendment 39-10, with 1 abstention, in 1915; 45-3, with 2 abstentions, in 1917. Joumal of the House of the Thirty-Sixth General Assembly of the State of lowa (Des Moines, 1915), 590-591; lowa House Joumal (Des Moines, 1917), 284; Joumal of the Senate of the ThirtySixth General Assembly of the State of lowa (Des Moines, 1915), 327; Iowa Senate Journal (Des Moines, 1917), 160. Referendum vote totals are from the Waterloo Evening Courier and Reporter, 18 October 1917, 3. The Iowa Official Register, a standard source for election returns, did not print the results of the 1917 prohibition referendum. 
(1919) session of the state legislature following congressional passage. ${ }^{6}$

Although Congress was moving toward nationwide prohibition at the time of the 1917 Iowa referendum, thereby suggesting the possibility that the October 15 election was not particularly important, voter turnout for the contest suggests a high degree of interest by lowa men. Over one-fourth (27.6 percent) more Iowans voted in the 1917 prohibition referendum than in the June 5, 1916 referendum on a proposed woman suffrage amendment to the state constitution, which was held in conjunction with the 1916 primary election. Considerably more men voted in the 1917 referendum than in either the 1918 gubernatorial election (12.4 percent more) or the 1918 contest for the United States Senate (21.7 percent more). Turnout for the 1917 referendum was almost five-sixths ( 82.8 percent) as large as for the 1916 presidential election. Regardless of their perceptions of a possible federal prohibition amendment in the near future, it is clear that Iowa men were vitally concerned about the proposed 1917 state prohibition amendment. ${ }^{7}$

Previous writers have discussed the early years of the temperance battle in Iowa at considerable length, with particular attention to the last two decades of the nineteenth century. ${ }^{8}$ Twentieth-century developments in the struggle between Iowa drys and wets, however, have yet to receive from historians the attention they deserve. This article attempts to fill

6. The lowa House voted $86-13$, with 9 abstentions, to ratify the Eighteenth Amendment. The Senate vote for ratification was 42-7, with 1 abstention. lowa House Journal (Des Moines, 1919), 81; lowa Senate Journal (Des Moines, 1919), 70.

7. lowa Official Register, 1917-1918 (Des Moines, 1917), 481 (woman suffrage referendum), 482-483 (presidential vote); Official Register, 1919-1920 (Des Moines, 1919), 363-366. Campbell, "Did Democracy Work," 89, notes a similar high voter turnout rate in the 1882 referendum.

8. The continuing emphasis on the late nineteenth-century phase of the lowa prohibition movement is also evident in such recent works as George W. McDaniel, "Prohibition Debate in Washington County, 1890-1894: Smith Wildman Brookhart's Introduction to Politics," The Annals of lowa 45 (Winter 1981), 519-536, and Thomas S. Smith, "The Murder of Reverend George C. Haddock: A Martyr for Prohibition," The Palimpsest 62 (November/December 1981), 186-193. 
one void in the history of the twentieth-century prohibition struggle in lowa by analyzing the vote in the 1917 referendum, and by comparing that vote with the tally in the 1882 special election. To facilitate a comparison of the 1917 vote with that in 1882 , and of the sources of support for prohibition in the World War I era with those of the 1880 s and 1890 s, the analysis will concentrate on an attempt to identify those groups of lowans who gave the most, as well as those who gave the least, support to prohibition in each of the two periods.

TABLE 1

IOWA ReFerendum Vote

OCTOBER 15, 1917

\begin{tabular}{lr}
\hline \hline $\begin{array}{l}\text { Proportion Voting } \\
\text { for Prohibition }\end{array}$ & $\begin{array}{r}\text { Number of } \\
\text { Counties }\end{array}$ \\
\hline under 20.0\% & 1 \\
$20.0-29.9 \%$ & 3 \\
$30.0-39.9 \%$ & 14 \\
$40.0-49.9 \%$ & 26 \\
$50.0-59.9 \%$ & 25 \\
$60.0-69.9 \%$ & 23 \\
$70.0-79.9 \%$ & 7 \\
\hline
\end{tabular}

Source: Waterloo Evening Courier and Reporter, 18 October, 1917, 3.

Although the statewide 1917 referendum vote was extremely close, with 49.9 percent of voters casting ballots for the proposed prohibition amendment, among the ninety-nine counties of the state considerable variation existed in the proportion of voters who cast affirmative ballots. The county vote for prohibition ranged from 76.7 percent in Ringgold, in the southern tier of counties, to only 19.3 percent in Dubuque, in the eastern tier. Ringgold and Dubuque were not the only counties in which the degree of support for prohibition differed greatly from the statewide figure. In eleven of Iowa's ninety-nine counties more than two of every three voters marked their ballots for prohibition. In seven counties, on the other hand, fewer than one-third cast dry ballots. Table 1 indicates the range in the degree of support for prohibition in Iowa counties. In the 1917 referendum, three types of counties gave considerably more support to the 
state prohibition proposal than others. They were Protestant counties, counties in which the largest proportions of men favored woman suffrage, and counties with the largest percentages of residents whose families had lived in the United States for at least three generations. Opposition to prohibition was strongest in the most German counties, in the most Catholic counties, and in counties where men demonstrated little support for woman suffrage. 9

As Table 2 indicates, the vote in the 1917 referendum corresponded more closely with the proportion of residents who were either first- or second-generation German-Americans than with any other variable, -.76. This indicates that German ancestry statistically explains $\mathbf{5 7 . 8}$ percent of the vote against prohibition. At first glance the strong relationship between German ancestry and opposition to prohibition may appear to be a specific illustration of a more widespread phenomenon, the opposition to prohibition of immigrants and their children, regardless of the country of birth of the foreign born. The -.66 correlation between the vote for prohibition and the proportion of residents who were either first-generation or secondgeneration Americans suggests this conclusion. When the firstgeneration and second-generation German-Americans are removed from the foreign-stock population, however, clearly neither opposition to nor support for prohibition corresponded closely with the proportion of residents who were born in foreign countries other than Germany, or whose immigrant parents were not of German birth. The correlation between the vote for prohibition and the proportion of non-German foreignstock residents was only -.19 , indicating that less than 4 percent of the wet vote can be explained by the relative number of firstgeneration and second-generation residents who could trace their ancestry to countries other than Germany. ${ }^{10}$

9. See Table 2 for the sources of the data used to determine the relationship between referendum voting behavior and each of several other variables. When the text refers to data listed in the tables, no further citations to those sources will be given.

10. The composition of the non-German foreign stock population was quite varied, as indicated in the following listing of the proportion of the nonGerman foreign stock population accounted for by each of the seven largest 


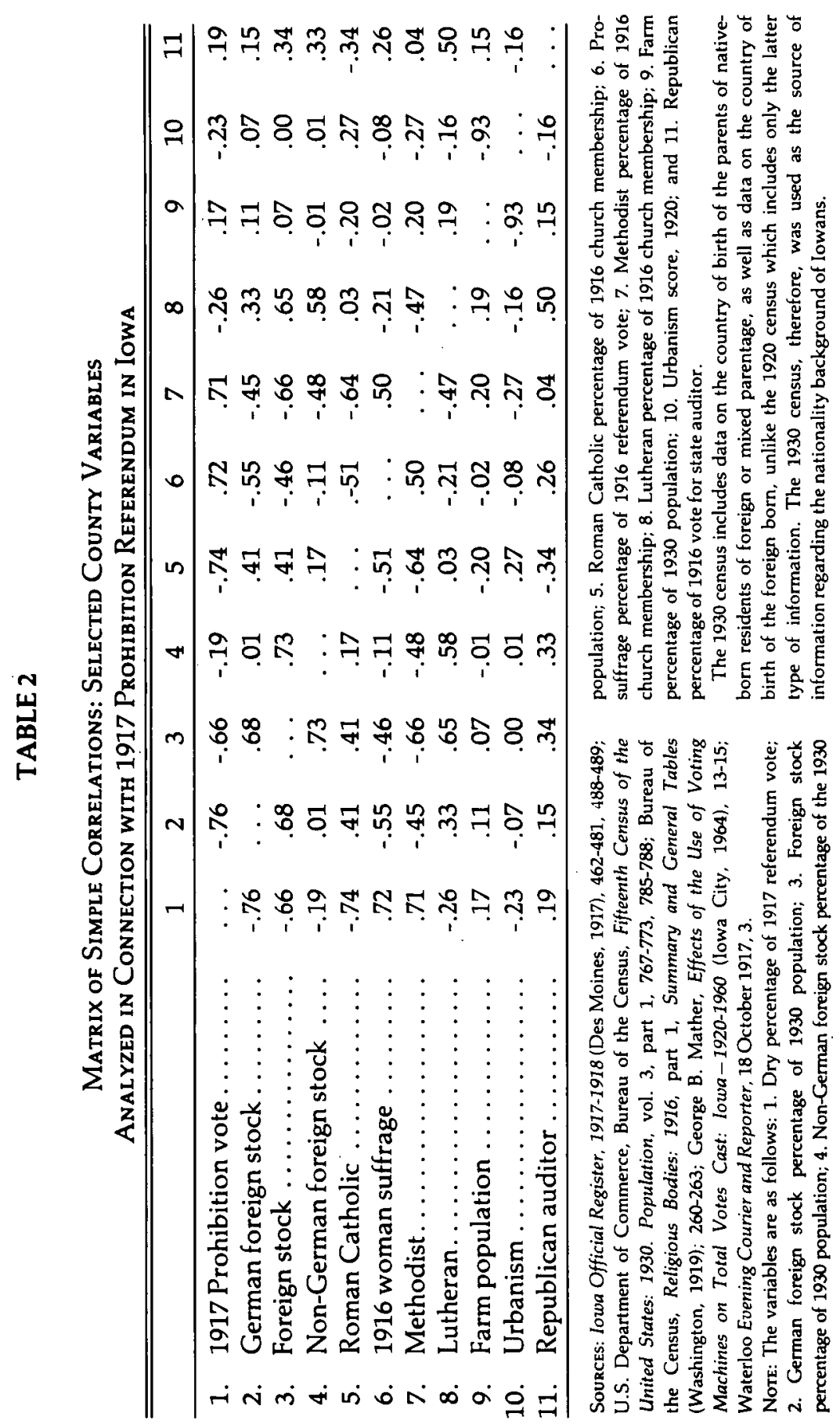


The 1917 Iowa vote against prohibition corresponded almost as closely with Roman Catholic church membership as with German ancestry, -.74 compared with -.76 . This indicates that over half (54.8 percent) of the wet vote can be explained by the Roman Catholic proportion of church members. Iowa Protestants, on the other hand, gave much more support to prohibition in the 1917 referendum, as the vote for the proposed amendment correlated with the proportion of church members affiliated with a Protestant body at .74. At the denominational level, however, the strength of the relationship between church membership and referendum voting behavior varied considerably. The correlation between the proportion of Methodists and the vote for prohibition was similar to that for all Protestant groups combined, .71, indicating that the relative size of Methodist church membership in Iowa counties explains just over half (50.4 percent) of the county-by-county variance in the dry vote. Lutheran church membership, on the other hand, correlated negatively, -.26 , indicating that the greater the proportion of Lutherans in Iowa counties the smaller the vote for prohibition. The relatively weak correlation also suggests that Lutheran church membership explains one-eighth as much of the vote against prohibition as does Catholic church membership, 6.8 percent compared with 54.8 percent.

Support for prohibition in lowa in 1917 was also strong in counties where relatively large proportions of men favored woman suffrage. The correlation between the 1917 referendum and a 1916 special election on a proposed woman suffrage amendment to the state constitution was .72 , very similar to the correlations between the prohibition vote and each of several other variables-German ancestry, Protestant church membership, and Methodist affiliation.

Unlike ethnicity, religion, and attitudes toward woman suffrage, each of which corresponded strongly with 1917 referendum voting behavior, neither community size nor political party affiliation correlated closely with voting on the

\footnotetext{
groups: Swedes -12.4 percent, Norwegians -12.3 percent, English -10.6 percent, Danes -10.3 percent, Irish -10.2 percent, Dutch -7.8 percent, and Czechs -6.7 percent.
} 
proposed prohibition amendment. As Table 2 indicates, the larger the percentage of the population living on farms, the larger the vote for prohibition. The .17 correlation, however, suggests that farm residence explains less than 3 percent of the vote for prohibition. A second measure of community size, the degree of urbanism within each Iowa county, points to a similar conclusion. Although the -.23 correlation indicates less support for prohibition in the more urban counties, the size of the coefficient suggests that less than 6 percent of the vote against prohibition can be explained by the degree of urbanization. Although the size of the dry vote corresponded positively with the Republican percentage of the vote for state auditor, the correlation was so small (.18) that it explains less than 4 percent of the prohibition vote. The correlation between the prohibition vote and the Democratic share of the vote for state auditor was -.19 , about the same strength as that between the Republican vote and the dry tally, although indicating an inverse relationship.

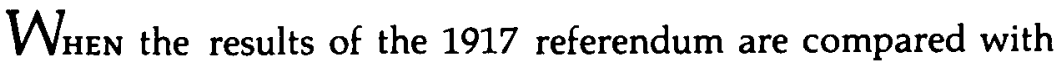
the vote in the 1882 referendum, as well as with recent historians' accounts of the prohibition movement in late nineteenth-century Iowa, it is clear that several important changes in the sources of support for prohibition occurred in the quarter-century before 1917. Although some of the groups which gave high levels of support to prohibition proposals in the 1880 s and 1890 s continued as late as 1917 to vote dryer than other groups of Iowans, by the latter date the correlates of support for prohibition were quite different than they had been twenty-five years earlier.

Previous accounts of the bases of support for prohibition in late nineteenth-century Iowa emphasize the close relationship between each of three independent variables and attitudes toward prohibition. The variables were political party preference, church membership, and nationality. Ballard Campbell, for example, concludes that, in the Iowa House of Representatives, "on liquor, the issue that most frequently separated them, the parties were uniformly consistent: Republicans always favored a restrictive policy and Democrats 


\section{Prohibition}

always supported a more lenient position. Not one roll call on the subject found the parties reversing this posture. . . . On the basic questions of prohibition and the status of the saloon, the Republicans predictably voted dry and the Democrats wet."11

Richard Jensen agrees with Campbell regarding the close relationship between partisan preference and attitudes toward alcoholic beverages. Jensen, however, goes on to suggest that the basic division on the question of alcohol was religious rather than partisan, with "pietists" advocating prohibition and "liturgicals" defending personal liberty, including the right to manufacture, sell, and consume beer, wine, and ardent spirits. ${ }^{12}$ Both Campbell and Jensen emphasize the close relationship between German ancestry and opposition to prohibition. When German lineage corresponded with a Democratic party preference and/or membership in a liturgical denomination, as it usually did in late nineteenth-century lowa, opposition to prohibition was almost complete.

Analysis of some basic quantitative data confirms Campbell's suggestions regarding the close relationship between political party preference and attitudes toward alcoholic beverages in late nineteenth-century lowa. As Table 3 indicates, both support for and opposition to the proposed 1882 prohibition amendment corresponded more closely with the voting behavior of Iowans in the 1880 presidential election than with any other variable. The relative size of the 1880 Democratic presidential vote in Iowa counties explains 56.3 percent of the variation in the vote against prohibition, while the 1880 Republican presidential vote explains over one-third (34.8 percent) of the dry vote. In 1917, on the other hand, partisan preference explained less than 4 percent of the referendum vote. Between 1882 and 1917, political party preference virtually disappeared as a discriminating variable in voting on the most divisive cultural issue in Iowa politics.

11. Campbell, Representative Democracy, 92. Although this statement refers to the Illinois, lowa, and Wisconsin lower houses, Campbell also notes that, "Party had the greatest hold over responses to temperance in lowa" (106).

12. Jensen, Winning of the Midwest, 58-88, especially 67-85. 


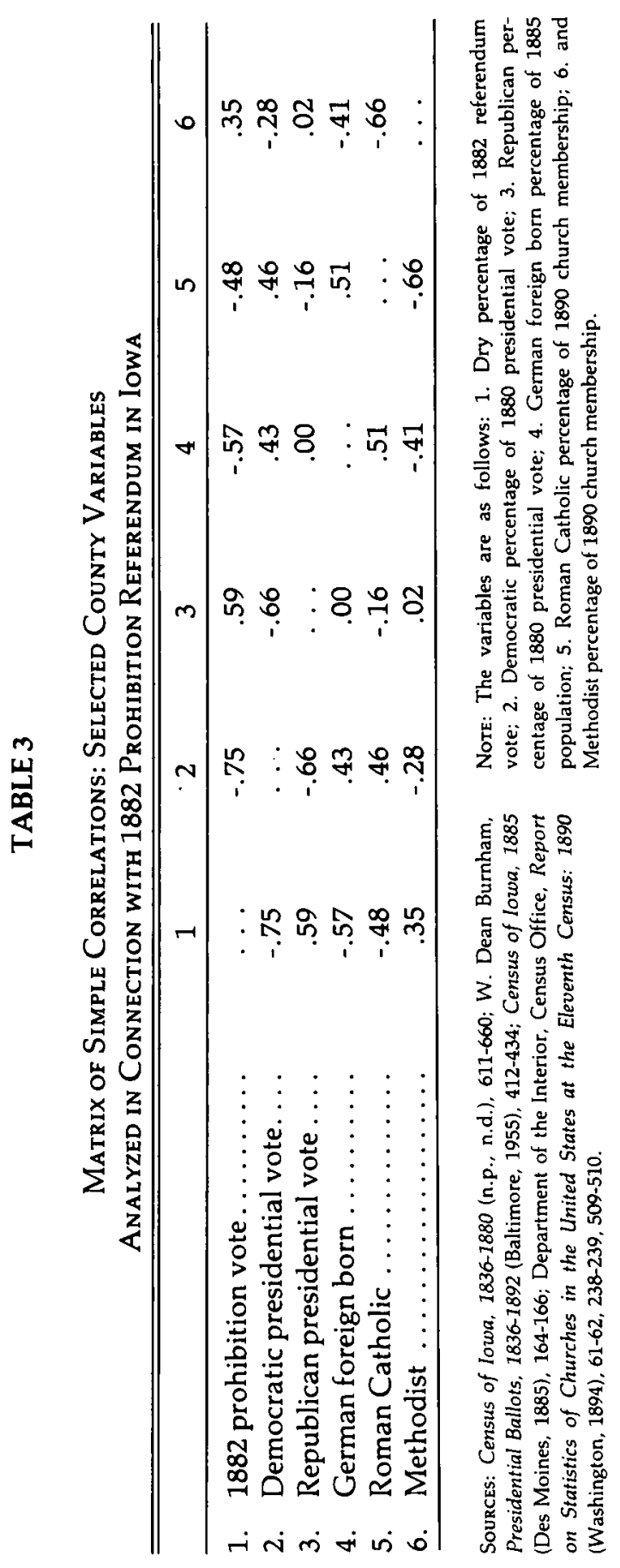




\section{Prohibition}

When we focus on nationality and religion, the other two variables emphasized by Campbell and Jensen in their explanations of the sources of dry and wet strength in late nineteenthcentury Iowa, we find a closer relationship between German ancestry and opposition to prohibition, as well as between Protestantism and support for prohibition, in 1917 than in 1882. German ancestry explained almost twice as much of the 1917 wet vote as it did of the 1882 wet vote, $\mathbf{5 7 . 8}$ percent compared with 32.5 percent. On the question of prohibition, German areas in Iowa voted considerably more distinctively in 1917 than they had in 1882 .

Because Jensen explains prohibition largely in terms of a religious universe of liturgicals and pietists, it is more difficult to compare his explanations of the relationship between religion and prohibition in the 1880s and 1890s with our 1917 data, which is organized along denominational lines. We can, however, compare both 1882 and 1917 referendum voting behavior with the proportion of church members in the largest liturgical denomination (the Roman Catholic church), and with the proportion in the largest pietist denomination (the Methodist Episcopal church). When this is done, it is clear that both Catholic allegiance and Methodist preference explained much more of the variation in 1917 referendum voting behavior than they explained in the 1882 special election. Roman Catholicism explained more than twice as much of the 1917 wet vote as of that in $1882,54.8$ percent compared with 23.0 percent. Methodism explained over four times as much of the 1917 dry vote as of that in 1882, 51.8 percent compared with only 12.3 percent. The relatively small correlation (.35) between the proportion of church members who were Methodist and the 1882 dry vote suggests that historians of popular voting behavior should continue to look at how voters in Methodist electoral districts marked their ballots compared with voters in other districts, as well as at the pronouncements of Methodist church officials and of denominational publications. Analysis of election returns and of church membership data indicates that rank-and-file voters in areas with large proportions of Methodists voted less distinctively in 1882 referendum balloting than the rhetoric of Methodist officials might suggest. By 1917, 
on the other hand, voting behavior in Methodist counties was much more congruent with the official teaching of Iowa's largest Protestant denomination.

When examining a social movement such as prohibition, which existed for several decades, historians should be alert to the possibility that the correlates of support for the movement may have changed one or more times during the history of the phenomenon. From this examination of Iowa, it appears that the bases of support for, and opposition to, prohibition shifted considerably between 1882 and 1917. Whether or not similar change occurred in other states can be determined by studying them at more than one point in time. Although the new political history and the new social history have added to our understanding of the role of temperance and prohibition in American history, it is possible that what we have learned from our studies of these phenomena in the 1880s and 1890s may not be accurate reflections of later dates such as the era of World War I. After we are satisfied that we have examined the early twentieth-century movement sufficiently, we could go on to the next stage in the battle for and against prohibition - the 1933 referenda held in most American states, including Iowa, on the question of repealing the Eighteenth Amendment. 
Copyright of Annals of Iowa is the property of State of Iowa, by \& through the State Historical Society of Iowa and its content may not be copied or emailed to multiple sites or posted to a listserv without the copyright holder's express written permission. However, users may print, download, or email articles for individual use. 